\title{
sciendo
}

\section{The Impact of Industry 4.0 on Export Market Orientation, Market Diversification, and Export Performance}

\author{
Alenka NAGLIČ, Polona TOMINC, Klavdij LOGOŽAR
}

University of Maribor, Faculty of Economics and Business, Razlagova 14, SI-2000 Maribor, Slovenia, alenkanaglich@gmail.com, polona.tominc@um.si, klavdij.logozar@um.si

\begin{abstract}
Background and Purpose: Existing literature on the Industry 4.0 concept does not provide a clear empirical verification if and how the implementation of Industry 4.0 impacts export market orientation, market diversification, and export performance of firms. The purpose of this paper is to provide a framework on how firms can increase their export performance by knowing the impact of Industry 4.0 on firms' export activities.

Methodology: The analysis is based on an examination of 81 Slovenian export firms, with the majority active in the processing industry in which the export of products and services represents a more than $20 \%$ share in the total revenue of the firm. Factor analysis and multiple regression were used to process the collected data.

Results: The analysis results reveal that firms that invest in advanced technologies and realize digital transformation are better prepared to compete internationally and achieve better export performance.

Conclusion: Our study showed the positive link between implementation of Industry 4.0 and export activities of firms and confirmed that implementation of Industry 4.0 leads to many changes in the mindset and operation of Slovenian firms and actively reflects in their export results. The research findings may serve as an important guide for managers in the optimal planning and management of export marketing and business activities. The study thus provides a foundation for the growing research on the relationship between Industry 4.0 and export business activities of firms.
\end{abstract}

Keywords: Industry 4.0, Export market orientation, Market diversification, Export performance.

\section{Introduction}

Industry $4.0^{1}$ is bringing many changes that represent numerous advantages or growth possibilities to firms, i.e. the possibility to expand to new, non-traditional markets, streamline products, adapt manufacturing without delays, and efficiently use resources and energy, in addition to causing firms to face new challenges.

Ganzarain \& Errasti $(2016,1122)$ deterimne that In- dustry 4.0 is a new phenomenon based on technological concepts of cyber-physical systems and Internet of Things and Services that has the potential to give rise to smart factories and influence every economic sector, especially industry. The phrase or abbreviation I 4.0 appeared in 2011 as a result of an association of representatives of German firms, politics, and academicians striving to boost the competitiveness of the German manufacturing industry based on high technology (Kagermann et al., 2011) as well as a

Received: 2nd February 2020; revised: 20th June 2020; accepted: 15th July 2020

${ }^{1}$ According to i-SCOOP (2020) Industry 4.0, which refers to the fourth industrial revolution (TechTarget, 2020), is the digital transformation of manufacturing/production and related industries and value creation processes. 
focus on smart - (a) smart products, (b) processes, and (c) procedures and factories (BMBF, 2017).

According to Kagermann et al. (2013), implementing Industry 4.0 will not only strengthen the competitive position of firms but also drive solutions to both global (e.g. resource and energy efficiency) and national challenges (e.g. managing demographic change) (Kagermann et al., 2013). Rodič $(2017,205)$ claims, that even when firms are not interested in implement $\neg$ ing the Industry 4.0 paradigm, the pressure from their competitors or partners will motivate them to do so. As suggested by Jerman et al. (2020, 69 and 75) it is also important to know and understand new competencies of employees such as technical literacy, information and communications technology (ICT) literacy, inovation and creativity, openness to learning, adaptation to change and various soft skills, introduced by the concept of Industry 4.0.

Prior researches revealed that Industry 4.0 encourages (a) the creation of new business models (Frank et. al., 2019; Müller et al., 2020) (b) transformation of internationalization processes (Strange \& Zucchella, 2017; Chiarvesio \& Romanello, 2018) and (c) impacts on firms' (export) performance (Dalenogare et al., 2018; Büchi et al., 2020).

While Grzybowska \& Łupicka $(2017,222)$ determine that the development of new technologies is the main driving force behind the contemporary global economy, Müller et al. (2018c) claim that strategic as well as operational opportunities are positive drivers of Industry 4.0 implementation, whereas challenges regarding competitiveness as well as organizational and production fit hinder its progress. Veile et al. (2019) expose seven dimensions, which need to be considered when implementing Industry 4.0: (1) corporate culture and communication, (2) personnel, (3) firm organization, (4) safety and security, (5) preparing the implementation of Industry 4.0 solutions, (6) integrating Industry 4.0 solutions and (7) financial feasibility.

Müller et al. (2018c) determine that the perception of Industry 4.0-related opportunities and challenges, which is the first step toward Industry 4.0 implementation, depends to a large extent on different firms' characteristics. According to Horvâth \& Szabó $(2019,119)$ multinational firms have higher driving forces and lower barriers to industry 4.0 than small and medium-sized firms.

The contemporary dynamics in the field of technology development and market globalization require firms to innovate and internationalize while also remaining competitive in the international marketplace (Bettiol et al. 2020). According to Hannibal \& Knight (2018), opportunities presented by Industry 4.0 might provoke firms to rethink their degree or geography of internationalization. While Strange \& Zucchella (2017) highlight the possibilities of the potential transformation that Industry 4.0 can have on the international dimension of firms, Chiavesio \& Romanello (2018) didn't confirm a direct relationship between Industry 4.0 and internationalization, but among other things encouraged scholars to research the relationship between investments in Industry 4.0 and the firm's strategy to remain competitive in the international context.

One of the latest researches (Bettiol et al. 2020) on the relationship between investments in Industry 4.0 and internationalization processes shows that the implementation of Industry 4.0 does not change the international strategy of the firms, but is mainly focused on finding coherence between the opportunities based on those technologies and the present strategy of the firms. Nevertheless, the authors Bettiol et al. (2020) argue that firms that source globally and export present the highest level of sensitiveness to global competition in the investments in Industry 4.0 technologies.

Despite the growing body of economic research on Industry 4.0, little attention has been paid to an examination of opportunities and challenges related to export business and performance of firms. The purpose of our study is to find out whether and how the implementation of Industry 4.0 reflects in firms' export business.

The main objective of this article is to examine if and how the implementation of Industry 4.0 encourages firms' export activities, such as (a) export market orientation and (b) market diversification - not only to traditional but also emerging markets (China, India, Vietnam, Turkey, Pakistan), and improves its export performance. Accordingly, this study attempts to answer the following research questions:

RQ1: How does the implementation of Industry 4.0 impact the export market orientation of firms?

RQ2: How does the implementation of Industry 4.0 impact the strategy of diversification to the dynamic markets of fast developing countries?

RQ3: How does the implementation of Industry 4.0 impact the export performance of firms?

More and more Slovenian firms are aware that digitalization of manufacturing is essential for improving competitiveness on domestic and foreign markets. In 2017, the industrial sector composed $32.2 \%$ of Slovenia's total GDP, which is an encouraging fact when compared to the industrial sector's share in the EU's total GDP of $25.1 \%$ in 2017 (CIA, 2020), however these data are accompanied by the questions, 'Which transformation phase are Slovenian firms currently in?' or 'Are they capable of introducing future technologies?' (Herakovič, 2016, 12).

In the further course of this paper, Chapter 2 describes the theoretical background, whereas Chapter 3 outlines the designing of the conceptual model and hypotheses. In Chapter 4, the empirical approach is described, encompassing a survey of 81 Slovenian export firms and the survey results. Chapter 5 presents a discussion, while Chapter 6 is closing the paper with a conclusion. 


\section{Literature review}

\subsection{Industry 4.0 and export activity}

According to Bettiol et al. $(2020,2)$ the new emerging paradigm of the fourth industrial revolution promises to redefine the sources of value through the exploitation of new sets of technologies such as co-robots, additive manufacturing, Internet of Things (IoT), big data, and artificial intelligence being directly connected to manufacturing.

Industry 4.0 has been one of the emerging topics in relation to international business in the last decade (Strange \& Zucchella, 2017; Chiarvesio \& Romanello, 2018).

The implementation of Industry 4.0 is an evolutionary process that requires current basic technologies and experiences to be adapted to the specific requirements of manufacturing engineering and innovative solutions for new locations and new markets to be explored (Kagermannn et al., 2013, 7).

Alcácer et al. $(2016,499)$ claim that the new techno-economic paradigm of the information age has brought about new structures and processes in international business. In their recent contribution, Bettiol et al. $(2020,1)$ highlight growing attention on the relationship between implementation of Industry 4.0 and internationalization processes. The authors (Bettiol et al., 2020, 9) argue that different level of internationalization impacts the motivation of implementation of Industry 4.0 technologies. According to the authors, emerging technologies can modify the scale and organization of manufacturing processes, potentially pushing firms toward the redefinition of their activities worldwide.

As reported by Laplume et al. (2016, 595), the implementation of new technology, such as 3D printing, has the potential to partially reverse the trend towards global specialization of production systems into elements that may be geographically dispersed and closer to the end users. Strange \& Zucchella $(2017,174)$ expose the importance of further growth of digital platforms for the distribution of products (e.g. Amazon, Alibaba), which make it easier for small firms to also enter global markets.

According to recommendations (Chiavesio \& Romanello, 2018) for future investigation on the relationship between Industry 4.0 and their related effects on the international configuration and performance of firms, the present study is focused on the importance and influence of Industry 4.0 on export activities of firms' and optimizing their export performance. In fact, no empirical evidences have been developed up now to test if and how Industry 4.0 is impacting firms' export activities, especially in terms of how their diversification strategies to untraditional, emerging markets are considered.

\subsection{Industry 4.0 and export market orientation}

A firm's export market orientation is based on the perception of the environment and on better knowledge of the needs, requirements, and wishes of foreign consumers. Export market-oriented firms are more informed about the needs of their target markets and will be positioned more strategically than their less market-oriented competitors to tailor products and services for those markets (Day \& Wensley, 1988).

The emergence of the information and digital age is rapidly changing the manner of international business activity (Alcácer et al., 2016). Industry 4.0 relies on the adoption of digital technologies to gather data in real time and to analyze it, providing useful information to the manufacturing system (Wang et al., 2016). Rezk et al. (2016) predict that emerging technologies will reshape the international configuration options available to firms.

As already stated, export market orientation is based on collecting, analyzing, and using information on foreign markets. It is also based on the formation of suitable export strategies in accordance with that information.

For instance, smart, connected products allow companies to form new kinds of relationships with customers, requiring new marketing practices and skill sets (Porter \& Heppelmann, 2014). In other words, as companies accumulate and analyze product usage data, they gain new insights into how products create value for customers, enabling better positioning of offerings and more effective communication of product value to customers (Porter \& Heppelmann, 2014).

According to the findings from the scientific literature on the impact of Industry 4.0 on firms' export market orientation, it can be assumed that emerging technologies are an important part of consolidating export market orientation.

\subsection{Industry 4.0 and diversification strategy (on emerging markets)}

The fast technological and communication progress in recent decades has operatively brought distant markets much closer and further encouraged firms to expand internationally, even though their operations are getting more complex with stronger internationalization due to the diverse cultural, institutional, and competitive environment.

According to Porter \& Heppelmann (2015), implementation of some Industry 4.0 technologies may have strong impacts on the firms themselves and even across their boundaries.

Although the literature highlighted (Strange \& Zucchella; 2017; Rehnberg \& Ponte, 2017) the importance of 
Industry 4.0 technologies in connection with developing international activities, Chiarvesio \& Romanello (2018) didn't confirm a direct relationship between Industry 4.0 and internationalization or any underlying impact in terms of internationalization.

On the other hand, different authors have speculated on how some new technologies may impact cross-border business. For example, 3D printing may alter the way production is organized across time and space - with important redistributive effects on geography and size of production activities (Rehnberg \& Ponte, 2018), while the digitalization that includes internet and mobile technologies with high-speed connectivity has helped bring about a change to established (export) business models (Roblek et al., 2016). In their recent contribution, Strange \& Zucchella (2017) discuss the potential implications of big data for international business. They determine that firms will be able to monitor emerging trends and opportunities in overseas markets without the need to make substantial resource commitments in local marketing affiliates, and that they will be able to more effectively optimize their supply, production, and distribution activities around the world.

The availability of good-quality big data will enable firms to analyze and operationalize them and realize the potential benefits (Strange \& Zucchella, 2017), which is particularly important in the case of firms that have the ambition to expand their business activities to international markets, especially fast growing, distant ones, which offer great business opportunities but represent a different business environment and weakly known culture and customer preferences.

It is evident that the young growing population with potential consumer power is an important driver for international business experts that want to pursue opportunities in the rising Asian and other emerging markets. Despite the fact that the world has changed dramatically as a result of the pandemic, the advanced economy group is forecast to grow at 4.5 percent in 2021, while growth for the emerging market and developing economy group is forecast at 6.6 percent in 2021 (IMF, 2020) - a great starting point to take advantage of the fourth industrial revolution, which offers an option of real-time international connectivity, product coordination, and customization of production without a time lag.

\subsection{Industry 4.0 and export performance}

Export performance is one of the most studied topics of international operations and the central construct in export marketing research (Cavusgil \& Zou, 1994; Leonidou, Katsikas \& Samiee, 2002). However, little is known about how firms see the potential contribution of Industry 4.0 related technologies for export performance.
Prior studies docu $\neg$ mented that new technologies, more efficient production techniques, and new products and processes resulting from technological innovation help exporting firms to respond to technological and environmental changes in highly competitive global markets (Kafouros et al., 2008; Zahra \& Covin, 1995), whereby the research of Azar \& Ciabuschi (2017) indicates that organizational innovation enhances export performance by sustaining technological innovation.

To achieve a competitive advantage, a company must be able to differentiate itself and thus command a price premium, operate at a lower cost than its rivals, or both. This allows for superior profitability and growth relative to the industry average (Porter \& Heppelmann, 2014). Azar \& Ciabuschi $(2017,333)$ are convinced that adopting innovations is vital to ensuring adaptive behavior by exporting firms.

Industry 4.0 is considered a new industrial stage in which vertical and horizontal manufacturing process integration and product connectivity can help companies to achieve higher industrial performance (Dalenogare et al., 2018). According to Haseeb et al. (2019) elements of Industry 4.0 such as big data, Internet of Things, and smart factory have a positive role in promoting information technology (IT) implementation, which contributes to sustainable firm performance. Adopting a higher number of smaller technological innovations enables exporting firms to better adjust to the new foreign environment and enhance their performance rather than focusing exclusively on radical innovations (Azar \& Ciabuschi, 2017, 333).

\section{Conceptual Model and Hypotheses}

Export market oriented firms operate on the basis of obtaining information that enables better understanding of consumers in foreign markets (Narver \& Slater, 1990), therefore we assume that the firms employing the new set of technologies, such as, in particular, Industrial IoT (Porter \& Heppelman, 2014; Strange \& Zucchella; 2017) and Big Data, which enable management of large amounts of data (Manyika et al., 2015; Strange \& Zucchella; 2017), will be more successful in developing export strategies. We can assume that the Industry 4.0 digital business environment promotes planning and making strategic export decisions on the basis of data on (potential) foreign market consumers, therefore we propose the first hypothesis:

Hypothesis 1: Industry 4.0 implementation positively impacts the export market orientation of firms.

We believe that in order to develop an appropriate strategy for the firm's market diversification to distant, fast developing markets, the ability of international networking in real time, adjusting production without delay, and coordinating products are of critical importance. These 
are the advantages brought about by the fourth industrial revolution (Müller et al., 2018a). The adoption of some Industry 4.0 technologies may cause (1) global value chain reconfiguration (Rehnberg \& Ponte, 2017), for example reverse the trends towards global specialization of production systems into elements that may be geographically dispersed and closer to the end users (Laplume et al., 2016, 595 ), or (2) optimization of firms' supply, production, and distribution activities around the world (Strange \& Zucchella; 2017), which is also reflected in the ambitions in formulating the firm's international market expansion, especially to distant, fast developing foreign markets that offer numerous business opportunities. This is grounds for our second hypothesis.

Hypothesis 2: Industry 4.0 implementation positively impacts the strategy of diversification to the dynamic markets of fast developing countries.

Researches argue that adopting innovations for the development of a foreign market is beneficial to export performance (Azar \& Ciabuschi, 2017; Büchi et al., 2020).
International competitiveness of firms is increasingly dependent on their competitive potential, therefore based on the results of previous research (Kafouros et al., 2008; Azar \& Ciabuschi, 2017), we believe that export firms will only be sufficiently responsive and competitive with regard to the environmental and technological challenges posed by the increasingly fierce competition in terms of market globalisation by adopting new technologies, effective production techniques, and new products and processes. From an IB perspective, we may expect that Industry 4.0 technology implementation influences the firms' ability to compete in national and regional foreign markets as well as cross-border optimisation of business processes and activities in the broader geographical area. In reference to this, we put forward the following hypothesis:

Hypothesis 3: Industry 4.0 positively impacts the export performance of firms.

Further on, we are introducing the conceptual framework, based on theoretical perspective and developed hypotheses (see Figure 1).

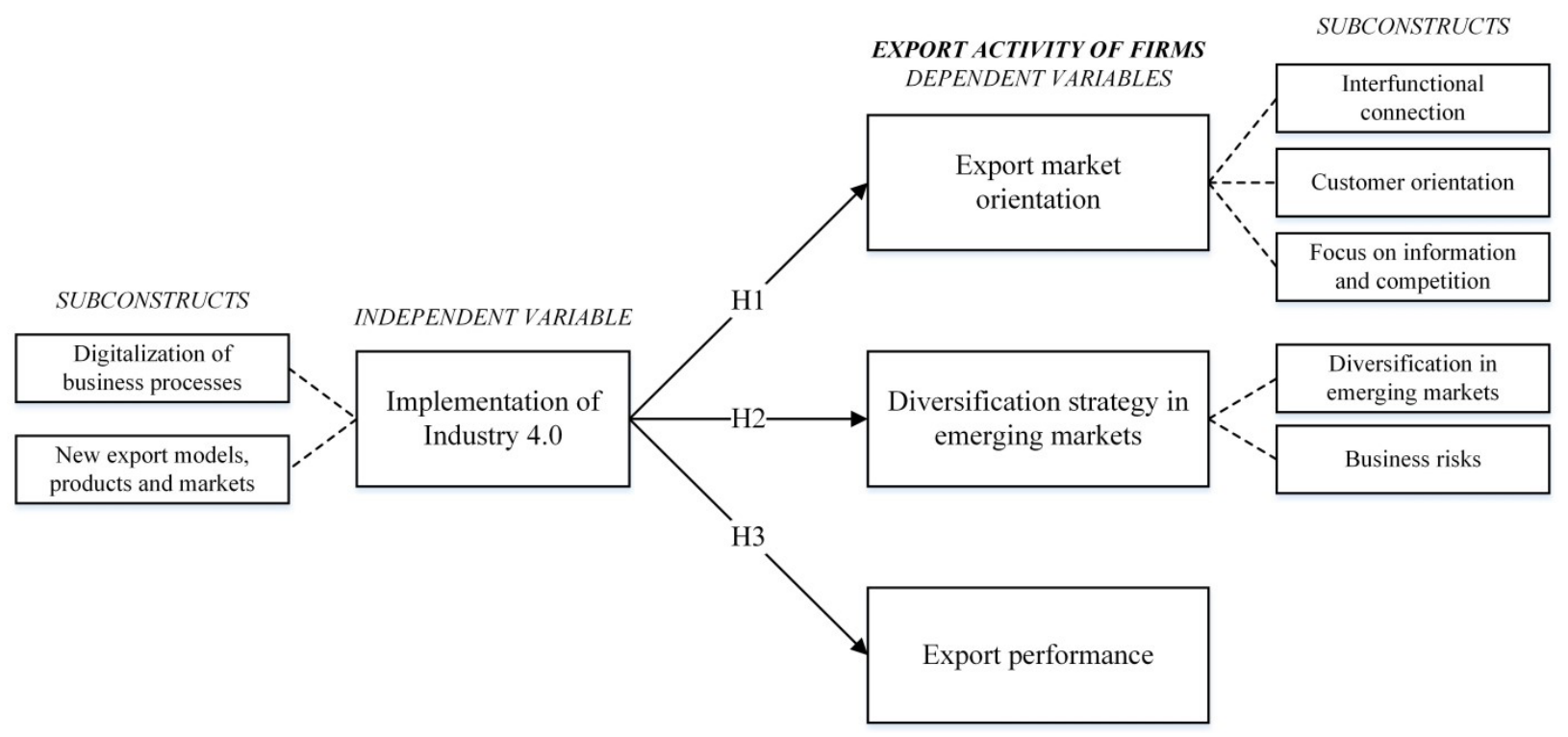

Figure 1: Conceptual model and hypotheses 


\section{Study methodology and sample}

\subsection{Questionnaire design}

In the first phase of the empirical study, we focused on designing relevant and reliable measurement scales by means of which we tried to study individual constructs as precisely as possible. Based on scientific literature, we searched for suitable measurement scales. If none were available, we designed them in accordance with the fundamental definitions of the constructs and drafted individual question banks. Questionnaire items are shown in the Appendix.

\subsubsection{Explanatory variable construct}

For the Industry 4.0 implementation explanatory variable construct in hypotheses $\mathrm{H} 1, \mathrm{H} 2$, and $\mathrm{H} 3$, we designed a new questionnaire comprised of items linked to the digitalization of operations (Herakovič, 2016; Kagerman et al,. 2013; Dais \& Bosch 2014), creation of new export strategies and models, a fast information flow, and a facilitated overcoming of temporal as well as geographic obstacles (Kagerman et al., 2013; Ganzarain \& Errasti, 2016). The construct was measured on the seven-point Likert scale. The questionnaire design takes into consideration important fields, such as the digitalization of business processes and the competitiveness of the firm, the creation of new business (export) models, a facilitated flow of information, and new - digital marketing channels.

\subsubsection{Dependent variable constructs}

a) Export orientation of firms - hypothesis H1 The Export orientation of Slovenian firms construct has been operationalized based on the shortened range of Narver and Slater statements, focusing on the market orientation dimension descriptions (Narver \& Slater, 1990). For the purposes of our study, the scale was additionally adapted in accordance with Cadogan et al. $(2009,86)$. When designing the scale or subscales, our point of view was just like for the authors of the information on export markets, the availability/dissemination of public information, and the responsiveness of the export firm or its employees. The questionnaire has been significantly shortened and simplified, as we were mostly interested in definitions that were focused on export market orientation, and we avoided posing questions and statements on related topics, because we did not want to deter the representatives of the firms surveyed from participating in a research as a result of too many statements to choose from. The construct was measured on the seven-point Likert scale.

b) Strategy of diversification to the dynamic mar kets of fast developing countries - Hypothesis H2

To measure the construct Strategy of diversification to the dynamic markets of fast developing countries, we created a new questionnaire based on the long-term marketing potentials of fast developing markets (PwC, 2017; Lins \& Servaes, 2002), the uncertainty of the business environment (Jurše, 2017), demographics (OECD, 2019), the capacities of the firm, and the skill set of the personnel (Sakarya et al., 2007; Jurše, 2017), due to the specific nature of the empirical study (non-traditional markets, young population, rising new purchasing power). The respondents evaluated individual statements based on the 7-point Likert scale.

c) Export performance - Hypothesis H3

The studying of export performance was focused on the factors that significantly influence the export performance of firms, i.e. their sales on foreign markets, export market share, entry into foreign markets, and the average annual sales growth in comparison to the average annual growth of their industry. The questionnaire was designed based on the measurement instrument developed by Cadogan et al. (2002). All four items were measured on the 7-point scale, with the first three items focused on measuring satisfaction ( 1 - very unsatisfied, 7 - very satisfied), and average annual sales growth focused on evaluating the achieved level (1 - very bad, 7 - very good).

\subsection{Applied methodology}

In order to test hypotheses $\mathrm{H} 1, \mathrm{H} 2$, and $\mathrm{H} 3$, the multidimensional dependent variables (export market orientation, strategy of market diversification to the dynamic markets of fast developing countries, and export performance) and the explanatory variable (Industry 4.0 implementation) were designed by means of factor analysis, whose applicability was tested beforehand by means of the Bartlett's test of sphericity and the Kaiser-Meyer-Olkin (KMO) index (Kaiser, 1974), which has to be above 0.5. The shared variance of an individual variable explained with all the factors together was verified by means of communalities. If an individual variable did not reach the prescribed value of 0.4 , it was removed from the analysis. In the further course of the factor analysis, we evaluated the dimensionality, validity, and reliability of the constructs. When determining a smaller number of factors, we used the rule of the own value, which has to be more than 1 for individual factors, as well as the rule of the entire explained variance, with the stipulated value of more than $60 \%$. The convergent validity of a construct was verified with the factor loading applying to the relevant factor. Loading values equal to or higher than 0.6 have confirmed the interconnection between variables measuring the same construct. The construct reliability or the consistency of individual factors was determined with the Cronbach Alfa Coefficient (Cronbach, 1951), with 
the prescribed value of at least 0.60 .

The dependability of a dependent variable on an explanatory variable or the created factors was studied by means of the regression analysis, which was performed separately for each of the hypotheses under the consideration of the value of the (multiple) correlation coefficient used to explain the correlation strength and the direction between dependent and independent variables as well as the value of the (multiple) coefficient of determination based on which the relationship between the explained and total variance for a dependent variable was determined. It was verified with the F-test if it is sensible to use the regression model, which demonstrates the suitability of a model as a whole or the existence of a linear relationship. Additionally, the T-test and statistical significance confirm the existence of codependency among variables. We took the $5 \%$ significance rate into consideration.

\subsection{Characteristic of the sample}

The survey questionnaire was distributed via e-mail at the beginning of April 2019 to 300 corporate addresses. We received 144 responses to the questionnaire by the end of April 2019. 63 firms were eliminated, because their responses were incomplete. Therefore, the final sample for the data analysis featured 81 firms that met all the conditions $(\mathrm{n}=81)$.

The email was addressed to the employees at one of the following positions in the firm: management board chairman or member, director of the firm, director or manager of the export department, director or manager of the marketing department, others (sales manager, chief digital information officer, financial analyst, head of controlling).

The survey is based on the examination of 81 Slovenian export firms, with the majority active in the processing industry (see Table 1) in which the export of products and services represents a more than $20 \%$ share in the total revenue of the company on foreign markets. Table 1 shows that the majority, i.e. $37 \%$ of the survey respondents, were small firms. The director function was the most common among survey respondents (43.2\%). 14.8\% of respondents declared themselves the director/manager of the export department, with the same share also attributed to other positions, such as marketing manager, controlling manager, sales manager, and other similar positions. The majority of firms participating in the study (Table 1) were processing firms $(34.6 \%)$ as well as information and communication firms $(17.3 \%)$. A striking $56.8 \%$ of the firms included in the study have been present on foreign markets for more than 11 years (Table 1 ).

It is evident from the data analysis results in Table 2 that as many as $64.2 \%$ of the participating companies realize the biggest share of their revenues on foreign markets through the export of products. Table 2 shows that exports account for 21 to $40 \%$ of the entire revenue of $42 \%$ of organizations participating in our study. The most important market category into which the largest export share (Table 2 ) of the respondent firms falls is developed markets, with a share of $88.9 \%$. As little as $1.2 \%$ of the firms participating in the study stated the independent markets category (e.g. Saudi Arabia - defined as a developing market, Botswana-defined as a frontier market).

Table 1: Profile of surveyed firms and respondents

\begin{tabular}{|l|c|c|}
\hline Size of the firm & $\mathbf{f}_{\mathbf{k}}$ & $\mathbf{f}_{\mathbf{k}_{\mathbf{k}}}$ \\
\hline Micro enterprises (1-10 employees) & 16 & 19.7 \\
\hline Small firms (11-50 employees) & 30 & 37.0 \\
\hline Mid-sized firms (51-250 employees) & 21 & 25.9 \\
\hline Large firms (251 + employees) & 14 & 17.3 \\
\hline Total & $\mathbf{8 1}$ & $\mathbf{1 0 0 . 0}$ \\
\hline Position & $\mathbf{f}_{\mathbf{k}}$ & $\mathbf{f}_{\mathbf{k}}$ \\
\hline Chairman/member of the management board & 10 & 12.3 \\
\hline Director of the firm & 35 & 43.2 \\
\hline Director/manager of the export department & 12 & 14.8 \\
\hline Director/manager of the marketing department & 10 & 12.3 \\
\hline Does not wish to respond & 2 & 2.5 \\
\hline Other & 12 & 14.8 \\
\hline Total & $\mathbf{8 1}$ & $\mathbf{1 0 0 . 0}$ \\
\hline
\end{tabular}


Table 1: Profile of surveyed firms and respondents (continues)

\begin{tabular}{|l|r|r|}
\hline Activity of the firm & $\mathbf{f}_{\mathbf{k}}$ & $\mathbf{f}_{\mathbf{k}}$ \\
\hline A - Agriculture and hunting, forestry, fisheries & 3 & 3.7 \\
\hline C - Processing & 28 & 34.6 \\
\hline F - Construction & 4 & 4.9 \\
\hline G - Sale, maintenance in repair of motor vehicles & 7 & 8.6 \\
\hline H - Transport and storage & 4 & 4.9 \\
\hline J - Information technology and communication & 14 & 17.3 \\
\hline F - Finance and insurance & 2 & 2.5 \\
\hline L - Real estate & 3 & 3.7 \\
\hline N - Other various business activities & 16 & 19.8 \\
\hline Total & $\mathbf{8 1}$ & $\mathbf{1 0 0 . 0}$ \\
\hline Presence on foreign markets & $\mathbf{f}_{\mathbf{k}}$ & $\mathbf{f}_{\mathbf{k}}$ \\
\hline Less than 1 year & 2 & 2.5 \\
\hline From 1 to 5 years & 17 & 21.0 \\
\hline From 6 to 10 years & 16 & 19.7 \\
\hline 11 years or more & 46 & 56.8 \\
\hline Total & $\mathbf{8 1}$ & $\mathbf{1 0 0 . 0}$ \\
\hline
\end{tabular}

Table 2: Export share in the entire revenue of the firm, strategic form of export internationalization, and the most important market category according to the Global Market Index.

\begin{tabular}{|l|r|r|}
\hline Share of export in the total revenue of the firm & $\mathbf{f}_{\mathbf{k}}$ & $\mathbf{f}_{\mathbf{k}}$ \\
\hline Between $21 \%$ and $40 \%$ & 34 & 42.0 \\
\hline Between $41 \%$ and $60 \%$ & 18 & 22.2 \\
\hline Between $61 \%$ and $80 \%$ & 8 & 9.9 \\
\hline More than $81 \%$ & 21 & 25.9 \\
\hline Total & $\mathbf{8 1}$ & $\mathbf{1 0 0 . 0}$ \\
\hline $\begin{array}{l}\text { Strategic form of export internationalization representing the } \\
\text { biggest export share for the company }\end{array}$ & $\mathbf{f}_{\mathbf{k}}$ & $\mathbf{f}_{\mathbf{k}}$ \\
\hline Product export & 52 & 64.2 \\
\hline Contract-based forms & 20 & 24.7 \\
\hline Direct investments & 9 & 11.1 \\
\hline Total & $\mathbf{8 1}$ & $\mathbf{1 0 0 . 0}$ \\
\hline $\begin{array}{l}\text { Most important market category according to the Global } \\
\text { Market Index representing the biggest export share for the } \\
\text { company }\end{array}$ & $\mathbf{f}_{\mathbf{k}}$ & $\mathbf{\mathbf { f } _ { \mathbf { k } }}$ \\
\hline Developed markets & 72 & 88.9 \\
\hline Developing markets & 8 & 9.9 \\
\hline Independent markets & 1 & 1.2 \\
\hline Total & $\mathbf{8 1}$ & $\mathbf{1 0 0 . 0}$ \\
\hline
\end{tabular}




\section{Results}

\subsection{Factor analysis results}

Based on the factor analysis, we established that the Industry 4.0 implementation construct is two-dimensional (Table 3), i.e. comprised of two subconstructs - digitalization of business processes and new export models, products, and markets. The two factors explain $81.94 \%$ of the total variance. Since the communality value was insufficient, we disqualified variable II4_3 in advance (a fast information and data flow makes it easier to overcome temporal and geographic obstacles) and repeated the factor analysis with the disqualified variable. The construct is convergently valid, since the rotated factor loadings for individual factors exceed 0.6. It is also reliable, which is evidenced from the Cronbach Alfa Coefficient that equals 0.781 for the construct.

The factor analysis results for the dependent variable Export orientation of Slovenian firms (Table 4) have shown that the construct is multidimensional. In accordance with the fundamental variables, we named the first factor or subconstruct Inter-functional connectivity, the second Consumer focus, and the third Focus on the information and competition on foreign markets. These three factors explain $96.18 \%$ of the variance. The rotated fac- tor matrix showed higher-than-prescribed rotated factor loadings for individual subconstructs also in this studied construct, therefore the entire construct is convergently valid. Suitable Cronbach Alfa Coefficient values confirm the reliability of the scale.

The rotated matrix for the Construct Diversification Strategy into the dynamic markets of emerging countries (Table 5) pointed us towards disqualifying two factors or subconstructs - Diversification to fast developing markets and Operational risks, which explain $89.48 \%$ of the entire variance. Due to an insufficient communality value, we disqualified fundamental variable DSDMEM_5 (We have suitably trained marketing experts for our entry on foreign markets) in advance and repeated the factor analysis with the disqualified variable. The Cronbach Alfa Coefficient values confirmed the reliability or consistency of both factors (subconstructs) as well as the entire construct.

Construct Export performance of firms is unidimensional (Table 6). After fundamental variable EP_1 (With our firm's sale to foreign markets in the last 3 years, we are: 1 - very unsatisfied, 7 - very satisfied) was disqualified for not having met the prescribed communality value of 0.4 and the factor analysis was repeated, the factor loadings are above 0.6 , which confirms the convergent validity of the construct. One single factor explains $76.82 \%$ of the entire variance. The Cronbach Alfa Coefficient value is 0.842 , making the scale reliable.

Table 3: Results of Factor Analysis for the Construct Implementation of Industry 4.0

\begin{tabular}{|c|c|c|c|c|}
\hline \multirow{2}{*}{\multicolumn{2}{|c|}{ Statement }} & \multirow{3}{*}{$\frac{\text { Communalities }}{0.735}$} & \multicolumn{2}{|c|}{ Factor loadings } \\
\hline & & & 1 & 2 \\
\hline II4.0_1 & $\begin{array}{l}\text { Digitalization of business processes is crucial for the } \\
\text { competitiveness of the firm. }\end{array}$ & & 0.857 & 0.008 \\
\hline II $4.0 \_2$ & $\begin{array}{l}\text { Industry } 4.0 \text { encourages executives to design new ex- } \\
\text { port strategies and models. }\end{array}$ & 0.869 & 0.180 & 0.915 \\
\hline II $4.0 \_4$ & $\begin{array}{l}\text { The implementation of digitalization is supervised by } \\
\text { competent executives. }\end{array}$ & 0.852 & 0.886 & 0.258 \\
\hline II $4.0 \_5$ & $\begin{array}{l}\text { The automation of manufacturing/business processes } \\
\text { encourages us to create new products and/or expand } \\
\text { to new markets. }\end{array}$ & 0.881 & 0.102 & 0.933 \\
\hline II $4.0 \_6$ & $\begin{array}{l}\text { New marketing (digital) channels are used to in- } \\
\text { crease export sales. }\end{array}$ & 0.761 & 0.855 & 0.172 \\
\hline \multicolumn{5}{|c|}{ Kaiser-Meyer-Olkin measure: 0.663; Chi-Square: 190.200} \\
\hline \multicolumn{5}{|c|}{$\begin{array}{l}\text { Cumulative percentage of explained variance for the first factor: } 54.73 \% \\
\text { Cumulative percentage of explained variance for the second factor: } 27.21 \%\end{array}$} \\
\hline \multicolumn{5}{|c|}{$\begin{array}{l}\text { Cronbach Alpha - all items (5): } 0.781 \\
\text { Cronbach Alpha - factor 1: } 0.850 \\
\text { Cronbach Alpha - factor 2: } 0.858\end{array}$} \\
\hline
\end{tabular}


Table 4: Results of Factor Analysis for the Construct Export Orientation of firms

\begin{tabular}{|c|c|c|c|c|c|}
\hline \multirow{2}{*}{\multicolumn{2}{|c|}{ Statement }} & \multirow{3}{*}{$\begin{array}{c}\text { Communalities } \\
\\
0.979\end{array}$} & \multicolumn{3}{|c|}{ Factor loadings } \\
\hline & & & 1 & 2 & 3 \\
\hline EO_1 & $\begin{array}{l}\text { We closely monitor the information on trends (e.g. pro- } \\
\text { visions, technological development, politics, economy on } \\
\text { export markets). }\end{array}$ & & 0.078 & -0.032 & 0.986 \\
\hline EO_2 & $\begin{array}{l}\text { We continuously plan and monitor the firm's activities con- } \\
\text { nected to meeting consumers' needs on foreign markets. }\end{array}$ & 0.980 & -0.027 & 0.989 & -0.029 \\
\hline EO_3 & $\begin{array}{l}\text { Executives in all positions in the firm are constantly in } \\
\text { contact with current and prospective consumers on foreign } \\
\text { markets. }\end{array}$ & 0.971 & 0.014 & 0.985 & -0.022 \\
\hline EO_4 & $\begin{array}{l}\text { Consumer satisfaction on foreign markets is often mea- } \\
\text { sured and carefully planned in advance. }\end{array}$ & 0.942 & -0.019 & 0.968 & -0.068 \\
\hline EO_5 & $\begin{array}{l}\text { Employees in the marketing department, along with em- } \\
\text { ployees from other departments in the firm, study future } \\
\text { requirements and needs of consumers on foreign markets. }\end{array}$ & 0.966 & 0.982 & 0.018 & 0.038 \\
\hline EO_6 & $\begin{array}{l}\text { Information on consumers on foreign markets is available } \\
\text { to everyone in the firm. }\end{array}$ & 0.906 & 0.942 & -0.071 & 0.119 \\
\hline EO_7 & $\begin{array}{l}\text { Executives frequently discuss advantages and strategies of } \\
\text { competitors on foreign markets. }\end{array}$ & 0.987 & 0.992 & -0.009 & 0.050 \\
\hline EO_8 & $\begin{array}{l}\text { All departments in the firm take part in the export opera- } \\
\text { tions. }\end{array}$ & 0.981 & 0.989 & 0.020 & 0.062 \\
\hline EO_9 & $\begin{array}{l}\text { We respond quickly to marketing and other competitive ac- } \\
\text { tivities of our competitors on foreign markets. }\end{array}$ & 0.978 & 0.096 & -0.066 & 0.982 \\
\hline EO_10 & $\begin{array}{l}\text { The export personnel are continuously in contact with the } \\
\text { manufacturing department. }\end{array}$ & 0.929 & 0.963 & -0.008 & 0.050 \\
\hline \multicolumn{6}{|c|}{ Kaiser-Meyer-Olkin measure: 0.801; Chi-Square: 1463.067} \\
\hline \multicolumn{6}{|c|}{$\begin{array}{l}\text { Cumulative percentage of explained variance for factor } 1: 48.43 \% \\
\text { Cumulative percentage of explained variance for factor } 2: 29.28 \\
\text { Cumulative percentage of explained variance for factor } 3: 18.47 \%\end{array}$} \\
\hline \multicolumn{6}{|c|}{$\begin{array}{l}\text { Cronbach Alpha - all items (10): } 0.814 \\
\text { Cronbach Alpha - factor 1: } 0.987 \\
\text { Cronbach Alpha - factor 2: } 0.981 \\
\text { Cronbach Alpha - factor 3: } 0.978\end{array}$} \\
\hline
\end{tabular}

\subsection{Hypotheses testing results}

In the further course of the empirical study, the hypotheses were verified by means of regression analysis. The results of individual models are shown in Table 7.

\section{Testing hypothesis $\mathrm{H1}$}

The results of the first regression model (Table 7) studying the impact of Industry 4.0 implementation on the export orientation of Slovenian firms show that the subconstruct digitalization of business processes (standardized regression coefficient $=0.267 ; \mathrm{p}<0.017$ ) has a statistically significant impact on the export orientation of Slovenian firms, while there is no direct connection between new export models, products, and markets as well as the export orientation of Slovenian firms, since the connection is not statistically significant. The R2 coefficient equals 0.076 and is statistically significant $(\mathrm{p}<0.050)$, which means that $7.6 \%$ of the variance of the export orientation construct can be explained through the variance of both variables together. The Durbin-Watson coefficient close to the prescribed value of 2 shows that there is no autocorrelation in the residuals. Firms that have digitalized their operations on all operational levels have shown a stronger export ori- 
Table 5: Results of Factor Analysis for the Construct Diversification Strategy into the dynamic markets of emerging countries

\begin{tabular}{|c|c|c|c|c|}
\hline \multirow{2}{*}{\multicolumn{2}{|c|}{ Statement }} & \multirow{3}{*}{$\frac{\text { Communalities }}{0.875}$} & \multicolumn{2}{|c|}{ Factor loadings } \\
\hline & & & 1 & 2 \\
\hline DSDMEM_1 & $\begin{array}{l}\text { For our industry, fast developing markets represent long-term } \\
\text { marketing potentials. }\end{array}$ & & 0.935 & -0.004 \\
\hline DSDMEM_2 & $\begin{array}{l}\text { The uncertainty of the business environment is one of the key } \\
\text { factors when deciding on entering the markets of fast develop- } \\
\text { ing economies. }\end{array}$ & 0.958 & 0.094 & 0.975 \\
\hline DSDMEM_3 & $\begin{array}{l}\text { The dynamic BRIC markets are crucial for the growth of our } \\
\text { firm. }\end{array}$ & 0.845 & 0.908 & 0.144 \\
\hline DSDMEM_4 & $\begin{array}{l}\text { We consider China and India to be among economically the } \\
\text { most dynamic and attractive developing markets. }\end{array}$ & 0.921 & 0.957 & 0.073 \\
\hline DSDMEM_6 & $\begin{array}{l}\text { The strategy of diversification to developing markets has been } \\
\text { assessed as risky. }\end{array}$ & 0.882 & 0.034 & $\mathbf{0 . 9 3 9}$ \\
\hline DSDMEM_7 & $\begin{array}{l}\text { We are interested in entering Asian developing markets with a } \\
\text { young geographic composition and a growing purchasing pow- } \\
\text { er. }\end{array}$ & 0.868 & 0.930 & 0.065 \\
\hline DSDMEM_8 & $\begin{array}{l}\text { We only opt for non-ownership forms when entering fast devel- } \\
\text { oping high-risk markets. }\end{array}$ & 0.972 & 0.088 & 0.982 \\
\hline DSDMEM_9 & $\begin{array}{l}\text { The marketing activity diversification strategy on developing } \\
\text { markets is designed in accordance with the firm's capacities. }\end{array}$ & 0.956 & 0.089 & 0.974 \\
\hline DSDMEM_10 & $\begin{array}{l}\text { The firm's international competitiveness is boosted with out- } \\
\text { ward internationalization to non-traditional, fast developing } \\
\text { markets. }\end{array}$ & 0.776 & 0.877 & 0.085 \\
\hline \multicolumn{5}{|c|}{ Kaiser-Meyer-Olkin measure: 0.795; Chi-Square: 1072.610} \\
\hline \multicolumn{5}{|c|}{$\begin{array}{l}\text { Cumulative percentage of explained variance for factor } 1: 52.23 \% \\
\text { Cumulative percentage of explained variance for factor } 2: 37.25 \%\end{array}$} \\
\hline \multicolumn{5}{|c|}{$\begin{array}{l}\text { Cronbach Alpha - all items (9): } 0.882 \\
\text { Cronbach Alpha - factor 1: } 0.956 \\
\text { Cronbach Alpha - factor 2: } 0.979 \\
\end{array}$} \\
\hline
\end{tabular}

entation. The new export models, products, and markets construct has a negative and statistically insignificant impact on the export orientation. The strength of the linear connection between the dependent and the independent variables is weak, since the $\mathrm{R}$ value in our case is only 0.274. Hypothesis H1 that Industry 4.0 implementation positively affects the export market orientation of Slovenian firms can only be partially confirmed.

\section{Testing hypothesis $\mathrm{H} 2$}

Model 2 (Table 7) was used to establish the effect of Industry 4.0 implementation on the strategy of diversification to the dynamic markets of fast developing countries. It can be concluded that the subconstruct of the digitalization of operations (standardized regression coefficient $=$ $0.267 ; \mathrm{p}<0.016$ ) positively affects the expansion of firms to developing markets. It has been established that the link between new export models, products, and markets and the expansion strategy to fast developing markets is not statistically significant. The adjusted coefficient of determination R2 equals 0.066 and is statistically significant $(p<0.026)$, which means that $6.6 \%$ of the variance of the diversification to the dynamic markets of fast developing countries strategy construct can be explained through the variance of both predictor variables. The Durbin-Watson coefficient is 1.787 , which excludes potential autocorrelation problems. Hypothesis $\mathrm{H} 2$ stating that Industry 4.0 implementation positively impacts the strategy of diversification to the dynamic markets of fast developing countries can thus only be partially confirmed. 


\section{Testing hypothesis $\mathrm{H3}$}

The results of the third regression model (Table 7) confirm that the subconstructs of business process digitalization (standardized regression coefficient $=0.855 ; \mathrm{p}<0.001$ ) and new export models, products, and markets (standardized regression coefficient $=0.172 ; \mathrm{p}<0.003$ ) have a statistically significant positive impact on the export performance of Slovenian firms. The effect of the digitalization of operations subconstruct on export performance is very strong, whereas the subconstruct of new export models, products, and markets only has a weak impact on the export performance of Slovenian firms. The adjusted coefficient of determination R2 equals 0.754 and is statistically significant ( $\mathrm{p}<0.026$ ), which means that $75.4 \%$ of the variance of the export performance of Slovenian firms construct can be explained through the variance of both predictor variables. The Durbin-Watson coefficient equals 1.580, so there is no danger of residual autocorrelation. It has been established that firms with digitalized operations as well as systematically designed new export models, products, and selected markets achieve better export performance compared to firms that have not (completely) digitalized their operations or are still insisting on traditional business models and product ranges as well as selected markets. Slovenian export-oriented firms will have to urgently follow the trends of digital transformation in the future, also when it comes to faster collection of important data and information from remote foreign markets. With timely recognition and fast reactions to customer requirements as well as thorough monitoring of the competition on foreign markets, firms boost their own competitiveness and increase their possibilities for maintaining/improving export performance. Hypothesis H3 stating that Industry 4.0 implementation positively impacts the export performance of Slovenian firms has therefore been confirmed in full.

\section{Discussion}

The aims of this study are to fill the voids in the extant literature by providing empirical confirmation of the impacts of Industry 4.0 implementation on export market orientation, market diversification to emerging markets, and export performance. This paper responds to calls for empirical research on Industry 4.0 technologies' impact on the international configuration and performance of firms (Chiarvesio \& Romanello, 2018).

At a general level, the results of this study show that implementation of Industry 4.0 is beneficial to export activities of firms. First, this study found that firms that digitize business processes (standardized regression coefficient $=0.267 ; p<0.017$ ) manage large volumes of data, including extensive information on customers and competitors in foreign markets, providing them with a better basis for achieving greater export market orientation, which is consistent with Strange \& Zucchella's $(2017,179)$ claims that firms, supported by BDA, will be able to monitor emerging trends and opportunities in overseas markets which exert big influence on the implementation of market orientation in the export context.

Second, our study seems to lead us to consider that subconstruct Digitalization of business processes (standardized regression coefficient $=0.267 ; \mathrm{p}<0.016$ ) has a strong impact on firms' international market expansion into emerging markets. Our finding is consistent with expectations and with lessons drawn from the literature (Azar \& Ciabuschi, 2017, Büchi et al., 2020), since we find that firms with certain ownership-specific advantages, such as innovative products, technological know-how, and market price leadership in competitive products, which are the result of digital transformation, often give firms a competitive edge in foreign markets. We also establish that due to

Table 6: Results of Factor Analysis for the Construct Export performance of firms

\begin{tabular}{|l|l|c|c|}
\hline \multicolumn{2}{|c|}{} & $\begin{array}{c}\text { Factor } \\
\text { loadings }\end{array}$ \\
\hline EP_2 & $\begin{array}{l}\text { Statisfaction (1 - very unsatisfied, 7 - very satisfied) } \\
\text { with the export market share of the firm in the last 3 } \\
\text { years. }\end{array}$ & 0.902 & $\mathbf{0 . 9 5 0}$ \\
\hline EP_3 & $\begin{array}{l}\text { Satisfaction (1 - very unsatisfied, 7 - very satisfied) } \\
\text { with the firm's entry onto foreign markets in the last } \\
\text { 3 years. }\end{array}$ & 0.698 & $\mathbf{0 . 8 3 5}$ \\
\hline EP_4 & $\begin{array}{l}\text { Achieved (1 - very low, 7 - very high) average annu- } \\
\text { al growth of the firm compared to the firm's industry } \\
\text { average growth. }\end{array}$ & 0.704 & $\mathbf{0 . 8 3 9}$ \\
\hline Kaiser-Meyer-Olkin measure: $0.588 ;$ Chi-Square: 128.089 & \\
\hline Cumulative percentage of explained variance for factor 1: $76.82 \%$ & & \\
\hline Cronbach Alpha - all items (3): 0.842 & \\
\hline
\end{tabular}


Table 7: Regression Analysis Results

\begin{tabular}{|c|c|c|c|c|c|c|c|}
\hline \multirow[b]{2}{*}{ Dependent variable } & \multirow[b]{2}{*}{ Independent variable } & \multicolumn{2}{|c|}{$\begin{array}{l}\text { Unstandardized } \\
\text { coefficients }\end{array}$} & \multirow{2}{*}{$\begin{array}{c}\text { Standardized } \\
\text { coefficients }\end{array}$} & \multirow[b]{2}{*}{$\mathbf{t}$} & \multirow[b]{2}{*}{ Sig. } & \multirow[b]{2}{*}{ VIF } \\
\hline & & B & $\begin{array}{l}\text { Std. } \\
\text { error }\end{array}$ & & & & \\
\hline \multirow[b]{2}{*}{$\begin{array}{l}\text { Export orientation } \\
\text { of Slovenian firms }\end{array}$} & $\begin{array}{l}\text { Implementation of Industry } 4.0 \\
- \text { Factor 1: Digitalization of } \\
\text { business processes }\end{array}$ & 1.871 & 0.764 & 0.267 & 2.449 & 0.017 & 1 \\
\hline & $\begin{array}{l}\text { Implementation of Industry } \\
4.0 \text { - Factor 2: New export } \\
\text { models, products and markets }\end{array}$ & 0.428 & 0.764 & 0,061 & 0.560 & 0.577 & 1 \\
\hline & \multicolumn{7}{|c|}{$\begin{array}{l}\text { Model 1: } \mathrm{R}=0.274 ; \mathrm{R} \text { - square }=0.076 \text {; Adjusted R-square }=0.051 ; \mathrm{p}<0.048 ; \text { Durbin-Watson }= \\
2.104\end{array}$} \\
\hline \multirow{3}{*}{$\begin{array}{l}\text { MODEL } 2 \\
\text { Diversification } \\
\text { strategy into dy- } \\
\text { namic markets of } \\
\text { emerging countries }\end{array}$} & $\begin{array}{l}\text { Implementation of Industry } 4.0 \\
- \text { Factor 1: Digitalization of } \\
\text { business processes }\end{array}$ & 2.181 & 0.884 & 0.267 & 2.467 & 0.016 & 1 \\
\hline & $\begin{array}{l}\text { Implementation of Industry } \\
4.0 \text { - Factor 2: New export } \\
\text { models, products and markets }\end{array}$ & 1.113 & 0.884 & 0.136 & 1.259 & 0.212 & 1 \\
\hline & \multicolumn{7}{|c|}{$\begin{array}{l}\text { Model 2: } \mathrm{R}=0.299 ; \mathrm{R} \text { - square }=0.090 ; \text { Adjusted R-square }=0.066 ; \mathrm{p}<0.026 \text {; Durbin-Watson }= \\
1.787\end{array}$} \\
\hline MODEL 3 & $\begin{array}{l}\text { Implementation of Industry } 4.0 \\
- \text { Factor 1: Digitalization of } \\
\text { business processes }\end{array}$ & 0.781 & 0.051 & 0.855 & 15.432 & 0.001 & 1 \\
\hline \multirow[t]{2}{*}{$\begin{array}{l}\text { Export performance } \\
\text { of Slovenian firms }\end{array}$} & $\begin{array}{l}\text { Implementation of Industry } \\
4.0-\text { Factor } 2: \text { New export } \\
\text { models, products and markets }\end{array}$ & 0.157 & 0.051 & 0.172 & 3.111 & 0.003 & 1 \\
\hline & \multicolumn{7}{|c|}{$\begin{array}{l}\text { Model 3: } \mathrm{R}=0.72 ; \mathrm{R} \text { - square }=0.761 ; \text { Adjusted R-square }=0.754 ; \mathrm{p}<0.000 ; \text { Durbin-Watson }= \\
1.580\end{array}$} \\
\hline
\end{tabular}

the possibility of international networking in real time provided by digitalisation of business processes, the firms are able to compete more easily also in distant, commercially attractive, fast developing markets. This finding is in line with (a) McKinsey's (2015) claims that firms need to drive the digital transformation of their business to succeed in the new environment and (b) the assertion that adoption of digital technologies can have significant implications for firms' international operations (Strange \& Zucchella, 2017). Müller and Voigt $(2018 b, 659)$ claim that Industrial Internet of Things (IIoT) confronts industrial manufactures with economic, ecological, as well as social benefits and challenges. In order to make sustainability potentials in firms accessible, concerns towards increasing competition, future viability as well as losing customer orientation should be addressed. Firms hereby need to find new or modified business models that address these concerns (Müller and Voigt, 2018b, 666).

While prior research argued that firms can benefit from Industry 4.0 in the attempt to innovate their business models through their digital transformation (Roblek et al.,
2016; Frank et al., 2019), we didn’t confirm an effect of subconstruct New export models, products, and markets in connection to Industry 4.0 technologies on developing cross-border activities, in other words on expansion into emerging markets, therefore this aspect is worth investigating in more detail in further research. The reason, among other things, might be that Slovenian firms in general are less digitally mature than other firms worldwide (Erjavec et al., 2018, 109).

Third, our research, in line with expectations, reveals that firms that introduce the emerging technologies of Industry 4.0 into their production or business processes achieve, according to the results of our analysis (standardized regression coefficient $=0.855 ; \mathrm{p}<0.001$ ) better export performance. As emerges from the extant literature, the different technologies that are included in the umbrella term Industry 4.0 (IoT, Big data and Analytics, Robotics, Additive Manufacturing) can have very diverse impacts on firms' export performance (Azar \& Ciabuschi, 2017; Bettiol et al., 2020). Dalenogare et al. (2018) determine that some of these technologies are positively associated to 
the expected benefits, while others are still at a very early stage of implementation and thus are without clear expected benefits. From this perspective, Industry 4.0 defines a new path for the competitiveness of the firms, especially in advanced countries, such as in Europe (WEF, 2018), that are nowadays particularly challenged by global competition and which might find in these technologies a new source of competitive advantage (Bettiol et al., 2020, 2).

\section{Conclusions}

The present study highlights the importance and influence of Industry 4.0 technologies on the creation of export activities of firms. Contrary to Chiarvesio \& Romanello's (2018) claims, we confirmed a direct relationship between implemented emerging technologies and cross-border processes, which is in line with Gerbert et al.'s (2015) findings that Industry 4.0 includes a range of new digital industrial technologies based on Internet of Things, BDA, and 3D printing that will strongly influence firms' international business activities.

According to Bettiol et al. (2020), the necessity to face global competition is one of the most compelling reasons for investing in Industry 4.0 technologies. This study confirmed this claim, as some of the emerging technologies (IoT, BDA) ensure much information on customers and competitors in foreign markets, which is of key importance for developing relevant export strategies.

In this study, based on the analysis of 81 Slovenian export firms with the majority active in the processing industry, we argued that firms can benefit from digital transformation in terms of expansion to foreign, more distant markets, which is in line with Porter \& Heppelman's (2015) work that attributes strong impact on cross-border business operations to some Industry 4.0 technologies.

The outcomes of this paper indicate that export business results are significantly related to effective performance of activities and actions that firms launch, direct, execute, and manage in their selected markets through their strategies, programmes, and operations (Jurše, 2017, 10) and are based on increased competitiveness through smart equipment, making use of information about highwage locations, demographic changes, resources, energetic efficiency, and urban production (Heck \& Rogers, 2014).

In summary, the current study documents the positive link between implementation of Industry 4.0 and (a) export market orientation, (b) exit internationalization into emerging markets, and (c) export performance.

\subsection{Implications for managers}

Industry 4.0 is bringing many changes that represent numerous advantages or growth possibilities for firms, i.e. the possibility to expand to new, non-traditional markets, streamline products, adapt manufacturing without delays, and efficiently use resources and energy, in addition to causing firms to face new challenges.

The findings of this study reveal that the business success of firms in international markets is significantly related to the managers' commitment to exploiting the opportunities and advantages provided to the firms by the emerging technologies, which is consistent with the finding of (a) Jurše $(2017,114)$ that in their efforts for cross-border market expansion, managers often come up against a series of restrictions resulting from various gaps in their own competitive potential and are reflected, inter alia, in insufficiently perfected technological competencies of the firm, or (b) with the claim of Chiarvesio \& Romanello (2018) that managers wishing to preserve competitiveness of their firms in the international arena invest in technological advances.

In the future, managers will ensure company performance mainly on the basis of good anticipation and formulation of customer demands as well as more efficient product distribution, which is inextricably linked to the implementation of digital technologies, such as BDA and IoT (Strange \& Zucchella, 2017, 181). This study confirmed this claim, as its results show that firms with digitalized operations as well as systematically designed new export models, products, and selected markets achieve better export performance.

The current study investigates whether and how the implementation of Industry 4.0 is related to the export activity of firms and whether it influences decisions regarding export market orientation and diversifications to emerging markets. The findings of this study reveal that firms that invest in advanced technologies and realize digital transformation are better prepared to compete internationally and achieve better export performance. The research findings may serve as an important guide for managers in the optimal planning and management of export marketing and business activities.

\subsection{Limitations and future avenues of research}

However, the study features several limitations. Every firm in the survey was represented by only one respondent, therefore the firm's opinion could only be presented unilaterally. Another limitation is the focus on Slovenian firms. This limitation should be kept in mind when generalizing the results and transferring them to different (more advanced level of digitization) countries or even cultural contexts (different export business practices).

The sample size $(\mathrm{n}=81)$, which is largely determined by the size of the country or, more precisely, the number of export firms, willing to correctly participate in the survey, prevented a more thorough comparison between industries. The study sample featured few firms that are active in 
non-manufacturing industries. The interpretation of findings reflects the general state of firms in all size brackets - from micro to large organizations.

We suggest that in the future the authors include a higher number of respondents in an individual firm, focus on the industry of an individual company, and also collect data for samples of countries that represent foreign markets in order to be able to make an international comparison. Moreover, future studies could investigate for instance, what kind of export (direct exporting, indirect exporting) and what kind of products (high-tech products, pharmaceutical products, vehicles) are supported by Industry 4.0. Therefore, we claim studies in the international management fields that carry on an in-depth analysis of export products, types of export business, potential export markets and activities in relation to the Industry 4.0 emerging technologies. This approach could clarify which products and types of exports, supported by Industry 4.0, could be implemented in order to increase international competitiveness and export performance.

\section{Literature}

Alcácer, J., Cantwell, J. \& Piscitello, L. (2016). Internationalization in the information age: A new era for places, firms, and international business networks? Journal of International Business Studies, 47, 499-512, https://doi.org/10.1057/ jibs. 2016.22

Azar, G. \& Ciabuschi, F. (2017). Organizational innovation, technological innovation, and export performance: The effects of innovation radicalness and extensiveness. International Business Review, 26 (2), 324-336, https://doi.org/10.1016/j.ibusrev.2016.09.002

Bettiol, M., Capestro, M., de Marchi, V., \& Di Maria, E. (2020). Industry 4.0 investments in manufacturing firms and internationalization. Marco Fanno Working Papers, 245.

BMBF - Bundesministerium für Bildung und Forschung. (2017). Industrie 4.0. Inovationen für die Produktion von morgen. https://www.bmbf.de/pub/Industrie 4.0.pdf Accessed 13 January 2019.

Büchi, M., Cugno, M., Castagnoli, R. (2020). Smart factory performance and Industry 4.0. Technological Forecasting and Social Change, 150, https://doi. org/10.1016/j.techfore.2019.119790

Cadogan, J. W., Diamantopoulos, A., \& Siguaw, J. A. (2002). Export Market-Oriented Activities: Their Antecedents and Performance Consequences. Journal of International Business Studies, 33 (3), 615-626, https://doi.org/10.1057/palgrave.jibs.8491036

Cadogan, J. W., Kuivalainen, O., \& Sundqvist, S. (2009). Export Market-Oriented Behaviour and Export Performance: Quadratic and Moderating Effects Under Differing Degrees of Market Dynamism and Interna- tionalization. Journal of International Marketing, 17

(4), 71-89, https://doi.org/10.1509/jimk.17.4.71

Cavusgil, S. T., \& Zou, S. (1994). Marketing strategy-performance relationship: An investigation of the empirical link in export market ventures. Journal of

Marketing, 58, 1-21, https://doi.org/10.2307/1252247

Chiarvesio, M., \& Romanello, R. (2018). Industry 4.0 Technologies and Internationalization: Insights from Italian Companies, van Tulder, R., Verbeke, A. and Piscitello, L. (Ed.) International Business in the Information and Digital Age. Progress in International Business Research, 13, 357-378, https://doi. org/10.1108/S1745-886220180000013015

CIA - Central Intelligence Agency. (2020). The World Factbook. Economy - overview. https://www.cia.gov/ library/publications/the-world-factbook/geos/ee.html. Accessed 20 April 2020.

Cronbach, L. J. (1951). Coefficient alpha and the internal structure of tests. Psychometrika, 16 (3), 297-334, https://doi.org/10.1007/BF02310555

Dais, S., \& Bosch, R. (2014). Industrie 4.0 - Anstoß, Vision, Vorgehen. In Bauernhansl, T., ten Hompel, M., \& Vogel-Heuser, B. (Eds.), Industrie 4.0 in Produktion. Automatisierung und Logistik, 625-634. Wiesbaden: Springer Vieweg.

Dalenogare, L. S., Benitez, G.B., Ayala, N. F., \& Frank, A. G. (2018). The expected contribution of Industry 4.0 technologies for industrial performance. International Journal of Production Economics, 204, 383-394, https://doi.org/10.1016/j.ijpe.2018.08.019

Day, G. S., \& Wensley, R. (1988). Assessing Advantage: A Framework for Diagnosing Competitive Superiority. Journal of Marketing, 52 (2), 1-20, https://doi. org/10.2307/1251261

Erjavec, J., Manfreda, A., Jaklič, J., \& Indihar Štemberger, M. (2018). Stanje in trendi digitalne preobrazbe v Sloveniji. [State and trends of digital transformation in Slovenia]. Economic and Business Review, 20, 109-128, https://doi.org/10.15458/85451.56

Frank, A. G., Mendes, G. H. S., Ayala, N. F., \& Ghezzi, A. (2019). Servitization and Industry 4.0 convergence in the digital transformation of product firms: A business model innovation perspective. Technological Forecasting \& Social Change, 141, 341-351, https:// doi.org/10.1016/j.techfore.2019.01.014

Ganzarain, J., \& Errasti, N. (2016). Three Stage Maturity Model in SME's towards Industry 4.0. Journal of Industrial Engineering and Management, 9 (5), 11191128, http://dx.doi.org/10.3926/jiem.2073

Gerbert, P., Lorenz, M., Rüßmann, M., Waldner, M., Justus, J., Engel, P., \& Harnisch, M. (2015). Industry 4.0: The Future of productivity and growth in manufacturing industries. Boston Consulting Group, 1-9. https:// image-src.bcg.com/Images/Industry_40_Future_of Productivity April 2015 tcm9-61694.pdf. Accessed 10 May 2020.

Grzybowska, K., \& Łupicka, A. (2017). Key competencies for Industry 4.0. Economics \& Management 
Innovations, 1 (1), 250-253, https://doi.org/10.26480/ icemi.01.2017.250.253

Hannibal, M., \& Knight, G. (2018). Additive manufacturing and the global factory: Disruptive technologies and the location of international business. International Business Review, 27 (6): 1116-1127, https://doi. org/10.1016/j.ibusrev.2018.04.003

Haseeb, M., Hussain, H. I., Slusarczyk, B., \& Jermsittiparsert, K. (2019). Industry 4.0: A Solution towards Technology Challenges of Sustainable Business Performance. Social Sciences, 8(5), 154, https://doi. org/10.3390/socsci8050154

Heck, S., \& Rogers, M. (2014). Are you ready for the resource revolution? McKinsey Quarterly, 2, 32-45.

Herakovič, N. (2016). Nekateri tehnološki izzivi Industrije 4.0. [Some technological challenges of Industry 4.0]. Ventil, 22 (1), 10-16.

Horváth, D., \& Szabó, R. Z. (2019). Driving forces and barriers of Industry 4.0: Do multinational and small and medium-sized companies have equal opportunities? Technological Forecasting \& Social Change, 146, 119-132, https://doi.org/10.1016/j. techfore.2019.05.021

IMF - International Monetary Fund. (2020). World Economic Outlook. Chapter 1-The great lockdown. https://www.imf.org/en/Publications/WEO/ Issues/2020/04/14/weo-april-2020. Accessed 3 May 2020.

I-SCOOP. (2020). Industry 4.0: the fourth industrial revolution - guide to Industrie 4.0. https://www.i-scoop. eu/industry-4-0/. Accessed 12 July 2020.

Jerman, A., Bertoncelj, A., Dominici, G., Pejić Bach, M., \& Trnavčević, A. (2020). Conceptual Key Competency Model for Smart Factories in Production Processes. Organizacija, 53 (1), 68-79, https://doi:10.2478/ orga-2020-0005

Jurše, M. (2017). Mednarodne strateške in kapitalske povezave [International strategic and capital alliances]. Maribor: University of msribor, Faculty of Economics and Business.

Kafouros, M. I., Buckley, P. J., Sharp, J. A., \& Wang, C. Q. (2008). The role of internationalization in explaining innovation performance. Technovation, 28, 63-74, https://doi.org/10.1016/j.technovation.2007.07.009

Kagermann, H., Lukas, W. D., \& Wahlster, W. (2011). Industrie 4.0: Mit dem Internet der Dinge auf dem Weg zur 4. industriellen Revolution. VDI Nachrichten, 13.

Kagermann, H., Wahlster, W., \& Helbig, J. (2013). Securing the future of German manufacturing industry. Recommendations for implementing the strategic initiative INDUSTRIE 4.0. Final report of the Industrie 4.0 Working Group. https://www.acatech.de/wp-content/uploads/2018/03/Final report Industrie 4.0 accessible.pdf. Accessed 14 January 2019.

Kaiser, H. F. (1974). An index of factorial simplicity. Psychometrika, 39 (1), 31-36, https://doi.org/10.1007/ BF02291575
Laplume, A. O., Petersen, B., \& Pearce, J. M. (2016). Global value chains from a 3D printing. Journal of International Business Studies, 47, 595-609, https:// doi.org/10.1016/j.techfore.2019.01.014

Leonidou, L. C., Katsikeas, C. S., \& Samiee, S. (2002). Marketing strategy determinants of export performance: A meta-analysis. Journal of Business Research, 55, 51-67, https://doi.org/10.1016/S01482963(00)00133-8

Lins, V. K., \& Servaes, H. (2002). Is Corporate Diversification Beneficial in Emerging Markets? Financial Management, 31 (2), 5-31, http://dx.doi. org $/ 10.2307 / 3666220$

Manyika, J., Chui, M., Bisson, P., Woetzel, J., Dobbs, R., Bughin, J., et al. (2015). The Internet of Things: Mapping the value beyond the hype. McKinsey Global Institute, (June) 144.

McKinsey \& Company. (2015). Industry 4.0: How to navigate digitalization of the manufacturing sector. https://www.mckinsey.com/business-functions/operations/our-insights/industry-four-point-o-how-to-navigae-the-digitization-of-the-manufacturing-sector. Accessed 2 May 2020.

Müller, J. M., \& Voigt, K.-I. (2018b). Sustainable Industrial Value Creation in SMEs: A Comparison between Industry 4.0 and Made in China 2025. International Journal of Precision Engineering and Manufacturing-green Technology, 5, 659-670, https:// doi.org/10.1007/s40684-018-0056-z

Müller, J. M., Buliga, O., \& Voigt, K.-I. (2018a), Fortune favors the prepared: How SMEs approach business model innovations in Industry 4.0? Technological Forecasting and Social Change, 132, 2-17, https://doi. org/10.1016/j.techfore.2017.12.019

Müller, J. M., Kiel, D., \& Voigt, K.-I. (2018c). What Drives the Implementation of Industry 4.0? The Role of Opportunities and Challenges in the Context of Sustainability. Sustainability, 10, 247, https://doi. org/10.3390/su10010247

Müller, J. M., Buliga, O., \& Voigt, K-I. (2020). The role of absorptive capacity and innovation strategy in the design of industry 4.0 business Models-A comparison between SMEs and large enterprises. European Management Journal, https://doi.org/10.1016/j. emj.2020.01.002

Narver, J. C., \& Slater, S. F. (1990). The Effect of a Market Orientation on Business Profitability. Journal of Marketing, 54 (4), 20-35, http://dx.doi. org/10.2307/1251757

OECD - Organization for Economic Co-operation and Development. (2019). Young population. https://data. oecd.org/pop/young-population.htm. Accessed 7 May 2019.

Porter, M. E., \& Heppelmann, J. E. (2014). How Smart, Connected Products Are Transforming Competition. Harvard Business Review, 92 (11), 64-88.

Porter, M. E., \& Heppelmann, J. E. (2015). How Smart, 
Connected Products Are Transforming Companies.

Harvard Business Review, 93, 1-37.

PwC-PricewaterhouseCoopers. (2017). The Long View.

How will the global economic order change by 2050?

https://www.pwc.com/gx/en/world-2050/assets/

pwc-world-in-2050-summary-report-feb-2017.pdf.

Accessed 30 April 2020.

Rehnberg, M., \& Ponte, S. (2016). 3D printing and global value chains: How a new technology my restructure global production. GPN Working Paper Series. Singapore: Global Production Networks Centre.

Rehnberg, M., \& Ponte, S. (2017). From Smiling to Smirking? 3D Printing, Upgrading and the Restructuring of Global Value Chains. Global Networks, 18 (1), 57-80, https://doi.org/10.1111/glob.12166

Rezk, R., Srai, J. S., Williamson, P. J. (2016).The impact of product attributes and emerging technologies on firms' international configuration. Journal of International Business Studies, 47, 610-618, https://doi. org/10.1057/jibs.2016.9

Roblek, V. Meško, M., \& Krapež, A. (2016). A Complex View of Industry 4.0. SAGE Open, Aprile-June, 1-11, https://doi.org/10.1177/2158244016653987

Rodič, B. (2017). Industry 4.0 and the New Simulation Modelling Paradigm. Organizacija, 50 (3), 193-207, https://doi:10.1515/orga-2017-0017

Sakarya, S., Eckman, M., \& Hyllegard, K. H. (2007). Market selection for international expansion. International Marketing Review, 24 (2), 208-238, https://doi. org/10.1108/02651330710741820

Strange, R., \& Zucchella, A. (2017). Industry 4.0, global value chains and international business. Multinational Business Review, 25(3), 174-184, https:// doi.org/10.1108/MBR-05-2017-0028

TechTarget. (2020a). Industry 4.0. https://whatis.techtarget.com/search/query?q=Industry+4.0. Accessed 12 July 2020.

Veile, J. W., Kiel, D., Müller, J. M., \& Voigt, K. I. (2019). Lessons learned from Industry 4.0 implementation in the German manufacturing industry. Journal of Manufacturing Technology Management, https://doi. org/10.1108/JMTM-08-2018-0270

Wang, S., Wan, J., Zhang, D., Li, D., \& Zhang, C. (2016). Towards smart factory for industry 4.0: a self-organized multi-agent system with big data based feedback and coordination. Computer Networks, 101, 158-168, https://doi.org/10.1016/j.comnet.2015.12.017

WEF - World Economic Forum. (2018). Readiness for the Future of Production Report 2018. http://www3. weforum.org/docs/FOP_Readiness_Report_2018.pdf. Accessed 2 May 2020.

Zahra, S. A., \& Covin, G. C. (1995). Contextual influences on the corporate entrepreneurship-performance relationship: A longitudinal analysis. Journal of Business Venturing, 10 (1), 43-58, https://doi. org/10.1016/0883-9026(94)00004-E
Alenka Naglič is a doctoral student at the Faculty of Economics and Business, University of Maribor. Her research interests are primarily focused on emerging markets and market diversification. She works as Marketing Specialist in the field of digitalization in the media industry.

Polona Tominc is a full -time Professor in the Department of Quantitative Economic Analysis at the Faculty of Economics and Business, University of Maribor. Her research is focused on statistical methods in economics and business sciences, especially in the field of entrepreneurship, gender differences and behavioural differences between social groups in different fields of management. She has published over sixty original scientific papers, with several of them in the Scopus or WoS databases and has participated at several scientific conferences.

Klavdij Logožar is an associate professor of international economy and business at University of Maribor, Faculty of Economics and Business. His research work is focused on logistics and supply chain management, international business and international strategic alliances. 


\section{Appendix}

\section{Implementation of Industry 4.0.}

II4.0 1: Digitalization of business processes is crucial for the competitiveness of the firm.

II4.0_2: Industry 4.0 encourages executives to design new export strategies and models.

II4.0_3: The rapid flow of information and data facilitates overcoming time and geographical barriers.

II4.0_4: The implementation of digitalization is supervised by competent executives.

II4.0_5: The automation of manufacturing/business processes encourages us to create new products and/or expand to new markets.

II4.0_6: New marketing (digital) channels are used to increase export sales.

\section{Export Market Orientation}

EO_1: We closely monitor the information on trends (e.g. provisions, technological development, politics, economy on export markets).

EO_2: We continuously plan and monitor the firm's activities connected to meeting consumers' needs on foreign markets.

EO_3: Executives in all positions in the firm are constantly in contact with current and prospective consumers on foreign markets.

EO_4: Consumer satisfaction on foreign markets is often measured and carefully planned in advance.

EO_5: Employees in the marketing department, along with employees from other departments in the firm, study future requirements and needs of consumers on foreign markets.

EO_6: Information on consumers on foreign markets is available to everyone in the firm.

EO_7: Executives frequently discuss advantages and strategies of competitors on foreign markets.

EO_8: All departments in the firm take part in the export operations.

EO_9: We respond quickly to marketing and other competitive activities of our competitors on foreign markets.

EO_10: The export personnel are continuously in contact with the manufacturing department.

\section{Diversification Strategy into the dynamic markets of emerging countries}

DSDMEM 1: For our industry, fast developing markets represent long-term marketing potentials.

DSDMEM_2: The uncertainty of the business environment is one of the key factors when deciding on entering the markets of fast developing economies.

DSDMEM 3: The dynamic BRIC markets are crucial for the growth of our firm.

DSDMEM 4: We consider China and India to be among economically the most dynamic and attractive developing markets.

DSDMEM_5: We have properly trained marketing professionals to enter the emerging markets.

DSDMEM 6: The strategy of diversification to developing markets has been assessed as risky.

DSDMEM_7: We are interested in entering Asian developing markets with a young geographic composition and a growing purchasing power.

DSDMEM_8: We only opt for non-ownership forms when entering fast developing high-risk markets.

DSDMEM_9: The marketing activity diversification strategy on developing markets is designed in accordance with the firm's capacities.

DSDMEM_10: The firm's international competitiveness is boosted with outward internationalization to non-traditional, fast developing markets.

\section{Export Performance}

EP_1: Satisfaction (1 - very unsatisfied, 7 - very satisfied) with the sales volume of our firm to foreign markets in the last 3 years.

EP_2: Satisfaction (1 - very unsatisfied, 7 - very satisfied $)$ with the export market share of the firm in the last 3 years.

EP_3: Satisfaction (1 - very unsatisfied, 7 - very satisfied) with the firm's entry onto foreign markets in the last 3 years.

EP_4: Achieved (1 - very low, 7 - very high) average annual growth of the firm compared to the firm's industry average growth. 